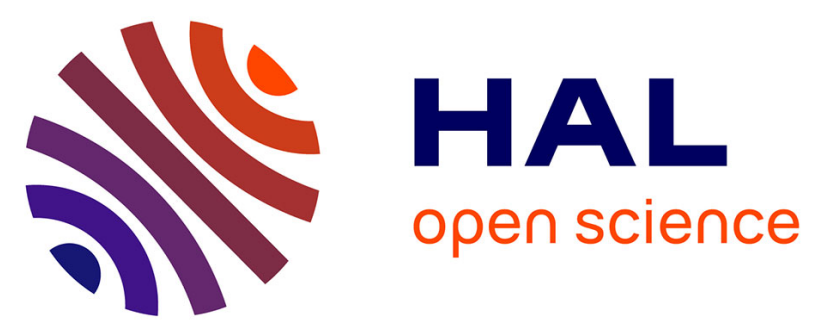

\title{
Fragmented Qrs Complex on a 12-Lead Ecg in Patients With Acute Myocardial Infarction: A MRI Study
}

Marion Angue, Luc Lorgis, Alexandre Cochet, Carole Richard, Alain Lalande, Marianne Zeller, Philippe Buffet, Isabelle L'Huillier, François Brunotte, Yves Cottin

\section{To cite this version:}

Marion Angue, Luc Lorgis, Alexandre Cochet, Carole Richard, Alain Lalande, et al.. Fragmented Qrs Complex on a 12-Lead Ecg in Patients With Acute Myocardial Infarction: A MRI Study. AHA scientific sessions, 2011, Orlando, United States. pp.12579. hal-00787540

\section{HAL Id: hal-00787540 \\ https://hal.science/hal-00787540}

Submitted on 14 Feb 2013

HAL is a multi-disciplinary open access archive for the deposit and dissemination of scientific research documents, whether they are published or not. The documents may come from teaching and research institutions in France or abroad, or from public or private research centers.
L'archive ouverte pluridisciplinaire HAL, est destinée au dépôt et à la diffusion de documents scientifiques de niveau recherche, publiés ou non, émanant des établissements d'enseignement et de recherche français ou étrangers, des laboratoires publics ou privés. 


\section{Abstract 12579: Fragmented Qrs Complex on a 12-Lead Ecg in Patients With Acute Myocardial Infarction: A MRI Study}

Marion Angue ${ }^{1}$; Luc Lorgis ${ }^{1}$; Alexandre Cochet ${ }^{1}$; Carole Richard ${ }^{1}$; Alain Lalande ${ }^{1}$; Marianne Zeller $^{2}$; Philippe Buffet ${ }^{1}$; Isabelle L'Huillier ${ }^{1}$; François Brunotte ${ }^{3}$; Yves Cottin ${ }^{1}$

${ }^{1}$ Cardiologie, Cntr Hospier Universitaire, Dijon, France

${ }^{2}$ LPPCE, IFR Santé STIC, Université de Bourgogne, Dijon, France

${ }^{3}$ IRM, Cntr Hospier Universitaire, Dijon, France

Objective: To investigate the relationship between a fragmented QRS complex (fQRS) and parameters of infarct size (IS) and no reflow assessed by cardiac magnetic resonance (CMR) in patients with acute myocardial infarction.

Patients and methods: Patients with a fQRS were compared with patients without fQRS.CMR was performed in 246 consecutive patients within the week following the AMI. Early and late gadolinium-enhanced images were examined to assess IS and microvascular obstruction. Left ventricular ejection fraction (LVEF) and left ventricular volumes were also determined.

Results: 128 (52\%) presented a fQRS on the first 12-lead ECG 36 hours post-AMI. Despite similar demographic, electrocardiographic and clinical features, patients with a fQRS were more likely to be male ( $85 \mathrm{vs.} 72 \%, \mathrm{p}=0.018$ ) and had a higher systolic blood pressure on admission (141 vs. $132 \mathrm{mmHg}, \mathrm{p}=0.005$ ). Furthermore, patients with a fQRS had a significantly lower LVEF, and larger IS than did patients without fQRS as assessed by CMR. Interestingly, myocardial perfusion abnormalities after infarction determined by first-pass perfusion images (microvascular obstruction=MO) and late perfusion images (persistent $\mathrm{MO}=\mathrm{PMO}$ ) were significantly more frequent in the fQRS group (Table 1). By multivariate logistic regression analysis, only infarct size (OR=0.456; 95\%CI: $1.03-1.07, \mathrm{p}=0.001)$ was an independent predictor of a fragmented QRS.Table 1: CMR data according to the presence of fQRS. N $(\%)$ or median $\left(25^{\text {th }}-75^{\text {th }}\right)$.

Conclusions: This population-based study revealed that fragmentation of the QRS is associated with increased IS and myocardial perfusion abnormalities, and decreased LVEF. These findings give further support to the argument that fQRS is a reliable marker of infarct size and could explain its strong prognostic value after AMI.

Author Disclosures: M. Angue: None. L. Lorgis: None. A. Cochet: None. C. Richard: None. A. Lalande: None. M. Zeller: None. P. Buffet: None. I. L'Huillier: None. F. Brunotte: None. Y. Cottin: None.

Key Words: CMR • Fragmented QRS • Myocardial Infarction • myocardial perfusion abnormalities 